\title{
An Examination of the Mediating Effect of Islamic Work Ethic on the Relationships between Transformational Leadership and Work Outcomes
}

\author{
Wahibur Rokhman \\ Sekolah Tinggi Agama Islam Negeri (STAIN) Kudus, Indonesia \\ Harif Amali Rivai \\ Andalas University, Padang, Indonesia
}

Abideen Adewale

International Islamic University, Malaysia

\begin{abstract}
This study investigates the role of Islamic work ethic as mediator between transformational leadership and work outcomes (organizational commitment, job satisfaction and turnover intention). This study used a sample of 370 employees from 60 Islamic microfinance institutions in Central Java, Indonesia. The results of Structural Equation Modeling (SEM) indicate that transformational leadership has a positively significant impact on Islamic work ethic. The findings also noted that Islamic work ethic directly and positively affect both organizational commitment and job satisfaction on the one hand, and negatively influences turnover intention on the other. Overall the model supported that Islamic work ethic has a significant role to mediate the the relationship betweem transformational leadership and work outcomes. Implication, limitation and suggestion for future research are discussed.
\end{abstract}

Abstrak: Studi ini meneliti peran efek mediasi dari etika kerja Islam dalam hubungan antara kepemimpinan transformasional dan hasil kerja (kepuasan kerja, komitmen organisasi dan intensi untuk keluar). Studi ini menggunakan sampel sebanyak 370 karyawan dari 60 lembaga keuangan mikro Islam di Jawa Tengah, Indonesia. Hasil dari persamaan struktural (SEM) menunjukkan bahwa kepemimpinan transformasional memiliki pengaruh yang signifikan terhadap etika kerja Islam. Selain itu, penelitian ini juga menemukan bahwa etika kerja Islam memiliki pengaruh positif langsung terhadap komitmen organisasi dan kepuasan kerja, dan berpengaruh negatif terhadap intensi untuk keluar. Secara keseluruhan model mediasi dari etika kerja Islam dalam hubungan antara kepemimpinan transformasional dan hasil kerja didukung secara empiris. Artikel ini juga mendiskusikan implikasi, keterbatasan serta saran pada penelitian selanjutnya.

Keywords: Islamic work ethic; job satisfaction and turnover intention; organizational commitment; transformational leadership 


\section{Introduction}

The study of work ethics has gained significant interest in recent years following the failures of major corporations like Enron, Arthur Anderson, and WorldCom. However, most studies in this area, as well as in the bigger subject area of business ethics, have been based on the experiences in American and European countries (Lim and Lay 2003; Rizk 2008). Essentially, these studies (Furnham 1982, 1990; Furnham and Rajamanickam 1992) relied on the Protestant Work Ethic (PWE) as advocated by Max Weber (Yousef 2001). Notwithstanding the impact of Protestantism and PWE on economic development in the West (Weber 2002), the generalizability of models that are based on these elements may be limited in Western societies, particularly those which adhere to other religious beliefs. Islam for example has its own concept of ethics that are derived from the Qur'an (divine revelation) and Hadith (the traditions of the Holy Prophet Muhammad PBUH). In a manner similar to Weberian Protestantism, Islam provides the ideological foundation for a variety of personal attributes that promote economic development (Ali 2005). Indeed, according to Ali (2005), the application of Islamic ethics brought the Moslems to the golden ages from the 8th until the 14th century.

The concept of work ethics in Islam, which is usually called Islamic work ethic, is a set of moral principles that distinguish what is right from what is wrong based on the Qur'an and Hadith, particularly in the work place (Ali 2005). However, not much is known about Islamic work ethic. To date, there are only a few researches that have looked at Islamic work ethic (e.g. Ali 1988; Yousef 2000, 2001; Rahman et al. 2006; Ali and Al-Kazemi 2007; and Khalil and AbuSaad 2009).

Critically, it is often argued that good leadership is a precursor to ethical behaviors in an organization. Indeed, over the years a number of researchers have suggested that leaders are responsible to create an organizational climate that either values or shuns ethics (Aswegen and Engelbreacht 2009). Moreover, leadership is regarded as one of the most important factors in motivating others to meet organizational goals (Frey et al. 2009). As such, over the years, researchers have been effectively seeking the answers to the critical question of what makes leaders effective. Among the approaches to the study of leadership, one of the best known is the transformational leadership framework (Bass 1985; Frey et al. 2009).

Previous studies have identified that transformational leadership has an impact on employees' attitudes, such as satisfaction, commitment, turnover intent, and organizational citizenship behavior (e.g. Podsakoff et al. 1996; Bass and Avolio, 1992). Moreover, Bass (1985) believes that transformational leaders are morally mature, and as such they are likely to display higher ethics. In this way, they will influence their followers to be more ethical and moral individuals (Bass and Steidlmeier 1999; Barling et al. 2008).

In the context of Islamic institutions, a Moslem leader is expected to follow the Islamic ethics in which they believe. This is expected to ultimately produce a significant effect on their subordinates' behavior. Quite a number of Quran readings and traditions of the prophet Muhammad (PBUH) emphasize the mutual interdependence and benefits between a transformational leader and the work outcome of his subordinates. In the Quran, Surah Al-Imran, chapter 3 verse 51, 
Allah enjoins a leader to demonstrate the power of his examples rather than the example of his powers. As such, he can arouse the sincere commitments of his subordinates to put in their very best effort. Moreover, in Islam the leader is expected to be positively exemplary. In this case, Allah SWT (Peace be Upon Him-PBUH) enjoins in Quran chapter 68 verse 4 , that a leader should be a role model both in speech and deeds. Cairnes (2003) logically provided a causal link among leadership, people, value, goals, relationship, culture and community. She stated that "when good leaders empower the right people, behind lived values and ambitious goals in a culture that encourages honesty, participation and innovation, profits and corporate longevity follow. (p. 2)"

Thus, the effect of leadership on employee outcomes may be mediated by Islamic work ethic. Unfortunately, mediation studies regarding transformational leadership and work outcomes are rare (see Pillai et al. 1999; Piccolo and Colquitt 2006; Asgari et al. 2008; Kirkman et al. 2009). In addition, there is the dearth of empirical studies that evaluate the mediating role of Islamic work ethic. Therefore, this study considers the role of work ethics in the relationship between transformational leadership and work outcomes. The current study attempts to explore how the relationship between transformational leadership and work outcomes could potentially be mediated by Islamic work ethic.

\section{Theoretical Background and Hypothesis}

\section{Transformational Leadership and Work Ethics}

The link between transformational leadership and ethics has aroused great interests among scholars. Burn (1978) considered morality as a basic foundation of theory of transformational leadership. He argued that transformational leadership occurs when one or more persons engage with others in such a way that the leaders and followers raise one another to a high level of motivation and morality (Krisnan 2001). Moreover, Bass (1985) believes that "authentic" transformational leaders are morally mature, and as such they are likely to display higher ethics. In this way, they will influence their followers to be more ethical and moral individuals (Bass and Steidlmeier 1999; Barling et al. 2008). Nevertheless, the issue of the relation between leadership and ethics has received less empirical support (Brown and Trevino 2006; Barling et al. 2008).

The study of ethics is about human relationships. It is about right and wrong and good and evil in the human inter-behavioral relationship. The term 'ethic' means something is morally good or considered morally right, as opposed to something which is legally or procedurally wrong. According to Thomas Aquinas, an Italian philosopher and theology, the ethical nature of one's behavior should be judged on the basis of three factors: (a) the motive of a person (which is the primary source of one's behavior), (b) the manifest behavior itself, and (c) the social context in which the behavior takes place (Kreeft 1990 in Kanungo 2001). Leadership has a significant role in the ethical guidance of an organization. Without ethical leadership, the organizations lose their long term effectiveness and become soulless structures (Kanungo 2001).

In the leadership literature, transformational leadership has become almost synonymous with the ethical leadership (Ciulla 2003). Burns' (1978) theory of transforma- 
tional leadership is compelling because it rests on a set of moral assumptions about the relationship between leaders and followers. Burns' theory provides a clear prescription about the nature of morally good leadership. He argues that the leaders have to operate at a higher need and value levels than those of their followers.

Bass and Steidlmeier (1999) mentioned that transformational leaders' behaviors and influential strategies have to meet high moral or ethical standards. They argued that only morally good leaders are authentic transformational leaders, while the rest, like Hitler, are pseudo-transformational. Bass and Steidlmeier (1999) described pseudo-transformational leaders as people who seek power and position at the expense of their followers' achievements. They discussed the moral components of transactional leadership by pointing out that the moral legitimacy of this leadership style depends on granting some liberty and opportunity to others than one claims for oneself, on telling the truth, keeping promises, distributing to each other what is due and employing valid incentives and sanctions.

Islam is a comprehensive system that manages the universal affairs on the basis of religion. Islam creates a balance between the material and the spiritual in every activity (Beekun 2007). Therefore, all activities conducted by Moslems should consider the vertical and the horizontal dimensions. That is, their activities should have benefit to humankind and permitted by Allah as well.

From the Islamic perspective, leadership is a form of trust (amanah). It represents a psychological contract between a leader and the followers that he/she will do his best to guide them, to protect them and to treat them fairly and justly. Therefore, the focus of leadership in Islam is on doing good (Beekun and
Badawi 1999). Leadership in Islam is based on the belief in and submission to the Creator, Allah. It centers on the subservience to Him (Beekun and Badawi 1999). The best role model of leadership in Islam is Prophet Muhammad (PBUH).

Muhammad (PBUH) was created and sent by Allah as an exalted standard of character (Qur'an chapter 68: verse 4) which should be followed by all the Moslems. The Prophet had a high quality level of ethics that was recognized not only by the Moslems at that time but also by the kuffar (disbelievers) in the Arabian Peninsula. Besides being a messenger of Allah, Muhammad (PBUH) was also a successful businessman. He conducted the business with a high ethical standard based on the Qur'an Al-karim. As a matter of fact, Muhammad (PBUH) was a transformational leader (Ali 2005), as he was the best model for all core leadership ethics. Muhammad (PBUH) was known as as-siddiq (the truthful) and al-amien (the trustworthy) even before he became the messenger of Allah (Beekun 2007). Therefore, Muhammad is a role model of ethics in business and work for Moslem.

The concept of the Islamic work ethic is originally from the Qur'an and the Prophet's deeds (Hadith). The prophet said anyone who worked hard caused sins to be absolved, and that no one ate better food than he who ate out of his work (Beekun 1997). IWE stresses creative work as a source of happiness and accomplishment (Yousef 2000). The Qur'an and the Hadith should be used as the basis of reference for activities by every Moslem irrespective of status. In Islam, leadership and ethics are very closely related with the iman (a Moslem belief system), and as such Moslem leaders should ideally use the iman as the basis for all their activities. 
The relationship between transformational leadership and work ethics has been examined by Schminke et al. (2002), Croker (2004), Engelbrecht et al. (2005) and Van Aswegen and Engelbrecht (2009). For instance, Schminke et al. (2002) explored the relationship between leadership and individual ethics in work group. The result showed that active leadership would lead to greater conformity with regards to the ethical frame work. Croker (2004) also found that transformational leadership closely correlated to the work ethics change. In addition, Engelbrecht et al. (2005) and Aswegen and Engelbrecht (2009) found that transformational leadership has a positive effect on ethical climate. Based on the literature above, it may be hypothesized that:

\section{$H_{1}=$ Transformational leadership will be positively related to Islamic work ethic.}

Islamic Work Ethic and Work Outcomes

Work ethics are closely related to job satisfaction (Yousef 2001; Koh and Boo 2001; Viswesvaran and Deshpande 1996; Vitell and Davis 1990). Understanding the relationship between work ethic and job satisfaction is essential in determining methods on intervention and strategies for mitigating factors that reduce satisfaction towards the work conditions (Yousef 2000). Robbins (2005) described job satisfaction as a collection of feelings that an individual holds towards his or her job. This means that an employee who has a high level of job satisfaction will hold positive feelings toward his/ her job and vice versa. Typically, job satisfaction is a person's evaluation of the overall quality of his or her present job. The evaluation measures may include either an effective orientation toward one's job or job position or an attitude one holds about the job (Spector 1997).
The relationship between work ethics and organizational commitment has been explored in the previous studies (e.g. Yousef 2001; Kidron 1979; Peterson 2003). Majority of organizational researchers have been studying organizational commitment in relation to various situational characteristics, attitudes and behaviors of employees. Moreover, according to Allen and Mayer (1990), the organizational commitment is a psychological state that attaches an employee to an organization, thereby reducing the incidence of turnover. Kidron (1978) further observed that work values show higher correlations with moral commitment to the organization than calculative commitment (Elizur and Koslowsky 2001). Putti, Aryee, and Ling (1989) analyzed the relationship between work values and organizational commitment based on a sample of workers in Singapore. They found that intrinsic work values relate more closely to organizational commitment than extrinsic work values.

On turnover intentions, studies showed the negative relation between work ethic and turnover intention. Sager et al. (1998) suggested that turnover intention is a mental decision intervening between an individual's attitude regarding a job and the stay or leave decision. Turnover intention refers to the three elements in the withdrawal cognition process: i) the thinking of quitting, ii) the intention to search for another job elsewhere and iii) the intention to quit (Mobley et al. 1979). A growing lack of loyalty has caused higher rates of turnover among employees seeking out new opportunities and larger career part (Abbasi and Hollman 2000).

The link between work ethics and job satisfaction, organizational commitment and turnover intention can be explained by the organizational justice theory (Koh and Boo 
2004). This theory explains that the justice perception of employees affect their job attitudes and organizational outcomes. Employees who perceive their organizations to be ethical are likely to perceive their organization as being fair to them. Thus, in turn, this is likely to enhance employee job satisfaction and organizational commitment, and also decrease turnover intention (Koh and Boo 2004). The previous researchers have showed that ethical conduct in the work influences job satisfaction, organizational commitment and reduces turnover intention (e.g. Weeks et al. 2004; Schwepker 2001). Furthermore, Kidron (1979) explores the link between Protestant Work Ethics and commitment to organization. The study revealed that work ethic is more related to moral commitment than calculative involvement. The study conducted by Yousef (2001) found that the Islamic work ethic directly effects both organizational commitment and job satisfaction. Likewise, Peterson (2003) found the relationship between ethical pressure and lower organizational commitment and higher intentions to leave the organization.

Based on the above discussion, the following hypotheses are discernable:

$H_{2}$ : Islamic work ethic is positively related to job satisfaction.

$\mathrm{H}_{3}$ : Islamic work ethic is positively related to organizational commitment.

$H_{4}$ : Islamic work ethic is negatively related to turnover intention.

The Mediating Effect of Islamic Work Ethic

In general, a given variable functions as a mediator to the extent that it accounts for the relationship between the predictor and the criterion (Baron and Kenny 1986). This study predicts that the Islamic work ethic will mediate the relationship of transformational leadership with job satisfaction, organizational commitment and turnover intention.

As earlier mentioned, transformational leadership is positively correlated with subordinate attitude and the organizational outcomes; such outcomes include: leadership effectiveness, organizational commitment, employee satisfaction and job performance (Bass 1990; Bass and Avolio 1993), organizational citizenship behavior and turnover intention (Podsakoff et al. 1996). Transformational leadership is also associated with the work ethics (Croker 2004; Schminke et al. 2002; Aswegen and Engelbreacht 2009).

The previous research has shown that work ethic is highly correlated with work outcomes (e.g. Greenberg 1990; Schminke et al. 1997 and Trevino and Weaver 2001). Thus, the relationship between transformational leaderships and work outcomes may be mediated by work ethics. In other words, as leaders follow the ethics which they belief in, they will thus fairly treat their followers. This will ultimately produce significant effect on their subordinates' behavior. This discussion suggests that work ethic will mediate the relationship between transformational and work outcomes, such as, job satisfaction, organizational commitment and turnover intention.

Based on review of the previous studies, the following hypothesis is proposed:

$H_{5}:$ Islamic work ethic mediates the relationship between transformational leadership and organizational commitment, job satisfaction, and turnover intention.

\section{Methodology}

\section{Sample}

The sample for this study consists of the staff members of the Islamic micro- 
finance institutions (IMFIs or BMTs) in Central Java, Indonesia. The focus of this study on Islamic microfinance institutions was motivated by several factors. First, there is an apparent dearth of studies on Islamic work ethic in organizations in general, and in particular those that adopt Islamic management philosophy. Therefore, the choice of Islamic microfinance in Central Java in this instance may have some contribution to Islamic microfinance development. Second, Islamic microfinance is still new in Indonesia, and its crucial implication for Indonesian economic development presupposes that this study may help to improve their managerial quality. Lastly, since this study incorporates Islamic work ethic as one of its latent construct, the Islamic institutions such as Islamic microfinance is therefore, appropriate to be the sampling unit of this study.

The current study utilizes a purposive sampling method for collecting the data. This method is a non-probability sample that conforms to certain criteria (Schindler and Cooper 2001). This method was appropriate for this study since some criteria would have to be met for a respondent to be selected. As such, valuable responses could be elicited from respondents who meet these afore set criteria as it relates to the subject matter of the study. The sample criteria used in this study were: (1) the managers under assessment should have been in their position for more than one year and (2) the staff must also have a length of service for not less than one year. These criteria were used in order to give a valid assessment since the leaders have used their style of management for more than one year and their subordinates might also have sufficient experience with their leaders.

Self-administered questionnaires were distributed to sixty Islamic microfinance institutions. Depending on the size of the in- stitution, between 5 and 15 questionnaires were administered in order to ensure proportionate representation. A total of 550 fulltime employees were requested to complete the questionnaires of which 419 were returned. The effective response rate is 76.2 per cent, which is rather high as per similar previous studies. About 49 respondents were excluded from further analysis due to non-fulfillment of the requirement (criteria) to be used as samples (32 respondents) and excessive missing data (17 respondents). The data in this instance were missing completely at random (MCAR). As suggested by Hair et al (2006), any remedy for missing data could be used. However, given sufficient sample size for the SEM, the authors preferred to exclude affected cases from further analysis. Therefore, the final sample size was 370 respondents. In order to reduce non-response bias, the respondents were reminded by calling their managers. The difference between late respondents and timely respondents would be considered an estimate of non-response bias. We did not find any differences, therefore it can be concluded that non-response biases did not occur in the samples.

On the basis of gender, 52 percent of the respondents are males. The majority of them (63 per cent) are under 30 years old. The education level reported that 65 percent hold a diploma or undergraduate degree. Furthermore, in terms of managerial tenure, 42 percent of the respondents have a length of tenure greater than 10 years, and the largest proportion of length of employment ranging between one to four years (60 percent). The main characteristics of the sample are presented in Table 1.

\section{Measurement}

The questionnaire used five-point Likert-type scales, ranging from 1 (strongly 
Rokhmanetal.

Table 1. The Characteristics of Respondents

\begin{tabular}{lcc}
\hline Demographic Variables & Frequency & Percentage \\
\hline $\begin{array}{l}\text { Gender } \\
\text { Male }\end{array}$ & 192 & $52 \%$ \\
Female & 178 & $48 \%$ \\
Total & 370 & \\
Age & & \\
18-24 & 96 & $26 \%$ \\
$25-29$ & 139 & $37 \%$ \\
$30-34$ & 77 & $21 \%$ \\
35-39 & 43 & $12 \%$ \\
40- above & 15 & $4 \%$ \\
Total & 370 & \\
Education Level & & \\
Junior high school & 4 & $1 \%$ \\
$\quad$ Senior high school & 121 & $33 \%$ \\
$\quad$ Diploma & 104 & $28 \%$ \\
Undergraduate & 137 & $37 \%$ \\
Postgraduate & 4 & $1 \%$ \\
Total & 370 & \\
Length of Employment \\
(years)
\end{tabular}

disagree) to 5 (strongly agree) of the items to measure the constructs of transformational leadership, Islamic work ethics, organizational commitment, job satisfaction, and turnover intention.

Transformational Leadership was measured by using the latest MLQ Form $6 \mathrm{~S}$ which consists of 12 -items. The MLQ includes questions that measure four factors of Transfor- mational leadership: (a) attributed idealized influence/charisma, (b) inspirational motivation, (c) intellectual stimulation, and (d) individual consideration. The reliability of composite variables is assessed using cronbach alpha. Hair et al. (2006) suggested that usual lower limit for Cronbach alpha is 0.70 , but in exploratory research this limit may decrease to 0.60 . The larger reliability of the construct 
will indicate the smaller the error. The scale of transformational leadership has reported reliabilities above 0.90. Islamic work ethic was measured using an instrument developed by Ali (1992). This instrument consisted of 17 items (short version). Example for these items include: laziness is a vice, dedication to work is a virtue, and justice and generosity in the work place are a necessary condition for the societal welfare, etc. This short version has been applied in several Moslem countries, such as, Saudi Arabia, UAE, Kuwait, and the result was relatively high. The Cronbach alpha of this scale was 0.85. Organizational Commitment was measured with a three-item version of the organizational commitment questioners (OCQ) adapted from Bozeman and Perrewe (2001). These items represented a global measurement of organizational, as used on the previous studies (see Luna-Arocas and Camp 2008). This short version was used since Allen et al (2003), comparing the long version and the short version found no substantive different result of general perception of organizational commitment. This scale has reported reliabilities above 0.88. Job Satisfaction was measured by the 3 item scale used by Dubinsky and Harley (1986). One characteristic example of job satisfaction scale is "generally speaking, I am satisfied with this job". This scale had a coefficient alpha of 0.89. Turnover Intention was measured using the two items adapted from the previous research (Hom and Griffeth 1991; Luna-Arocas and Camp 2008). For example: "I consider taking another job". This scale has reported reliabilities above 0.80 .

\section{Analysis}

Data analysis was conducted in two stages. Firstly, checking for data entry includes validity and reliability of variables, identifi- cation of outliers and normality of the data. The composite variables (summated scales) were produced to represent each of these constructs by, firstly, reverse-scoring individual items (where necessary), and secondly, by taking the average across the items proposed a priori to represent each construct. Using a composite variable is purported to reduce the number of variables in a structural model, therefore, it is likely to improve model parsimony (Schumacker and Lomax 1996). Validity of instruments was assessed by Confirmatory Factor Analysis (CFA). Secondly, testing of a fit model was conducted by using Structural Equation Modeling (SEM). AMOS 7.0 computer program was utilized to run data from questionnaires. 'Goodness-of-fit' models were assessed by three criteria: absolute fit measure, incremental fit measure and parsimonious fit measure (Table 2).

\section{Results}

\section{Psychometric Properties of the Scales}

Validity of each construct was tested using principal component analysis (PCA) to assess whether the items represent a single underlying construct. Unidimensionality of the construct can be demonstrated by extracting a single component with an eigenvalue greater than 1. Furthermore, items with factor loading that are 0.50 or greater; are considered practically significant (Hair et al. 2006). Results of PCA asserted that all constructs indicated single underlying construct.

Correlations, means, and standard deviations for all variables are presented in Table 3. The estimated correlation matrix for the constructs shows that estimated correlation 
Table 2. Evaluation of SEM with Goodness-of-fit Measures

\begin{tabular}{|c|c|c|}
\hline Types Measures & Goodness-of-fit Measures & Level of Acceptable \\
\hline \multirow{3}{*}{ Absolute fit measure } & \multirow{3}{*}{$\begin{array}{l}\text { Goodness of fit index (GFI) } \\
\text { Root mean square error of } \\
\text { approximation (RMSEA) } \\
\text { Adjusted goodness-of-fit } \\
\text { index (AGFI) }\end{array}$} & Greater than 0.90 \\
\hline & & Under 0.08 \\
\hline & & Greater than 0.90 \\
\hline \multirow{3}{*}{ Incremental fit measure } & \multirow{3}{*}{$\begin{array}{l}\text { Tucker Lewis index (TLI) } \\
\text { Normed fit index (NFI) } \\
\text { Comparative fit index (CFI) }\end{array}$} & Greater than 0.90 \\
\hline & & Greater than 0.90 \\
\hline & & Greater than 0.90 \\
\hline Parsimonious fit measure & Normed-chi-square $\left(\chi^{2} / \mathrm{df}\right)$ & $\begin{array}{l}\text { Lower limit } 1.0 \\
\text { Upper limit } 2.00 / 3.00 \\
\text { or } 5.00\end{array}$ \\
\hline
\end{tabular}

Source: Adopted from Tabachnick and Fidell (2001); Hair et al. (2006); Byrne (2001)

among constructs do not indicate a multicollinearity problem of lack of discriminate validity in which all correlation values are lower than 0.70 . The correlations among some of this study's variables also provided initial support for the hypotheses. In support of $H_{1}$ that transformational leadership was positively correlated with Islamic work ethic, the result showed that transformational leadership was significantly correlated with Islamic work ethic $(r=0.340, p<0.01)$. In addition, Islamic work ethic was positively correlated with organizational commitment $(\mathrm{r}=0.346, \mathrm{p}<0.01)$, job satisfaction $(\mathrm{r}=$ $0.370, \mathrm{p}<0.01)$ and negatively correlated with turnover intention $(\mathrm{r}=-0.156, \mathrm{p}<0.01)$. These results are consistent with the existing literature.

The current study utilizes the structural equation modeling (SEM) to examine the theoretical model. This method is an extension of the general linier model (GLM) which was used to test the causal effect among the main construct of the hypothesized model (Byrne 2005; Kline 2005; McDonald and Ho 2002). Accordingly, the SEM process consists of two steps: testing the measurement model through confirmatory factor analysis and, testing the structural model (Bollen 1989; Byrne 2005; Kline 2005; McDonald and Ho 2002). Hair et al. (2006) recommended that the measurement model be evaluated before constructing the structural model.

\section{Test of the Measurement Model}

The main purpose of a measurement model is to describe how well the observed indicators serve as a measurement instrument for the latent variables (Kline 2005). It means that the measurement model depicts the link between the latent variables and the observed measures. The test of measurement model was conducted using the confirmatory factor analysis (CFA). Assessments of goodness of fit of each measurement model were determined by several criteria: Chi-square, Root 
Table 3. Means, Standard Deviations, and Correlations between Variables

\begin{tabular}{lcccccc}
\hline \multicolumn{1}{c}{ Variable } & Mean & SD & 1 & 2 & $\mathbf{3}$ & $\mathbf{4}$ \\
\hline 1. Transformational leadership (1) & 3.74 & 0.49 & 1.00 & & & \\
2. Islamic Work Ethic (2) & 4.14 & 0.35 & $0.340^{* *}$ & 1.00 & & \\
3. Organizational commitment (3) & 4.03 & 0.55 & $0.336^{* *}$ & $0.346^{* *}$ & 1.00 & \\
4. Job Satisfaction (4) & 3.79 & 0.62 & $0.437^{* *}$ & $0.370^{* *}$ & $0.409^{* *}$ & 1.00 \\
5. Turnover Intention (5) & 2.00 & 0.79 & $-0.255^{* *}$ & $-0.156^{* *}$ & $-0.245^{* *}$ & $-0.134^{* *}$ \\
\hline
\end{tabular}

Notes: $* *$ is significant at $\mathrm{p}<0.01$

Table 4. Results of Confirmatory Factor Analysis

\begin{tabular}{lccccccc}
\hline \multicolumn{1}{c}{ Model } & $\chi^{2}$ & DF & $\chi^{2} /$ DF & GFI & TLI & CFI & RMSEA \\
\hline Cut-off point & & & $<3$ & $>0.90$ & $<0.90$ & $>0.90$ & $<0.08$ \\
$\begin{array}{l}\text { CFA of Transformational } \\
\text { Leadership }\end{array}$ & 374.4 & 131 & 2.74 & 0.95 & 0.93 & 0.95 & 0.069 \\
$\begin{array}{l}\text { CFA of Islamic work } \\
\text { Ethic }\end{array}$ & 424.9 & 119 & 1.45 & 0.99 & 1.00 & 1.0 & 0.00 \\
CFA of Work outcomes & 46.1 & 24 & 1.92 & 0.98 & 0.98 & 0.99 & 0.050 \\
CFA of all variables & 341.1 & 128 & 2.665 & 0.91 & 0.92 & 0.93 & 0.067 \\
\hline
\end{tabular}

Mean Square Error of Approximation (RMSEA), Tucker-Lewis Index (TLI), Goodness-of-fit Index (GFI) and Comparative Fit Index (CFI). The CFA was conducted separately for each variable.

The summary of the measurement analyses is shown in Table 4. An examination the link between observed and unobserved variables is necessary to prove that each of the measurement models is a single factor model. This may also imply a closeness of the model to the sample data on the basis of the goodness-of-fit criteria. The results of CFA supported that the measurement model of each construct indicated that the theoretical model meet cut-off-point for all indicators. Therefore, all the constructs achieved an acceptable fit to the data.

\section{Test of the Structural Model}

The subsequent analysis for testing overall model and developed hypotheses utilized structural equation modeling using the AMOS 7.0 program. An objective of the testing is to assess the goodness of fit between the model and the sample data (Byrne 2001). Hair et al (2006) recommended three type of goodness-of-fit measures, namely absolute fit measures, incremental fit measures, and parsimonious fir measures. Test statistics for parameter 
estimates were assessed by critical ratio (c.r.). They represent the parameter estimate divided by standard error. Critical ratio values that are larger than 1.96 prove the path coefficient to be statistically significant at level $\mathrm{p}<0.05$. The chi-square of the theoretical model was 18.601 with 5 degree of freedom (df). This is statistically significant at level $\mathrm{p}<0.001$. A non-significant chi-square shows support for believing that the differences of the predicted and actual matrices are non-significant and it indicates an acceptable fit (Hair et al. 2006), therefore a non-significant chisquare is desired. Statistical significance level of chi-square indicates the probability that the differences are due solely to sampling variation. However, "statistical non-significance does not assure the researcher that another model would not fit as well or better" (Hair et al. 2006: 654). In addition, the chisquare values are sensitive to sample size. If the sample size becomes large enough, significant differences will be found for specified model. Using the $c^{2}$ index represents little guidance in determining the extent to which the model does not fit (Byrne 2001). For this reason other fit indices ( $\mathrm{c}^{2} / \mathrm{df}$; GFI; RMSEA; AGFI; TLI; NFI; CFI; RMR), that may minimize the effect of sample size, are utilized to assess the fit model. The result of the structural equations test of the composite variables indicated that the theoretical model achieved an acceptable fit to the data, $\left(\mathrm{c}^{2} / \mathrm{df}\right.$ $=2.86 ; \mathrm{GFI}=0.90 ; \mathrm{RMSEA}=0.071 ; \mathrm{AGFI}$ $=0.94 ; \mathrm{TLI}=0.91 ; \mathrm{NFI}=0.92 ; \mathrm{CFI}=0.94$; RMR $=0.027$, which is above the cutoffs for good fit.

Hypothesis 1 investigated the relation between transformational leadership and Islamic work ethic. The result of the AMOS 7 analysis showed the relation between transformational leadership and Islamic work ethic. This is presented in Figure 1 and Table
3. The results of assessment of the structural model showed that the standard path coefficients of 0.42 were significant at $\mathrm{p}<0.01$ which supported the hypothesis. Furthermore, the data showed that Islamic work ethic has significantly positive direct effect on both organizational commitment and job satisfaction with the standard path coefficient 0.41 and 0.49 . These relationships were significant at $\mathrm{p}<0.05$. As such, hypotheses 2 and 3 were supported. The results of analysis also supported that the Islamic work ethic has significant negative effect on turnover intention $(-0.16, \mathrm{p}<0.01)$, this result supported $\mathrm{H}_{4}$.

In order to test for the mediation, two structural equation models using AMOS 7 were developed and compared. The first model was the mediation model asserting the link between transformational leadership and work outcomes through Islamic work ethic as shown in figure 1. The second model was the no mediation model; this model described the link directly from transformational leadership to work outcomes by excluding Islamic work ethic from the model. This method is justifiable as demonstrated in previous studies (see Koh and Boo 2001 and Chen 2005). The results showed that the model did not meet the goodness of fit criteria. It can be concluded that the former model was better than the later. These findings were supported by greater value of GFI, AGFI, NFI, TLI, and lower value of $\div^{2} / \mathrm{df}$ and RMSEA. Therefore, it was revealed that the mediating effect of Islamic work ethic was supported.

\section{Discusion}

The results of the structural equation modeling indicated that transformational leadership explained more than 40 per cent of the variance in Islamic work ethic. The finding of this study suggests that transforma- 
tional leadership has significant impact on the Islamic work ethic behavior among the staff members in Islamic microfinance institution in the study area. Furthermore, the result indicates that the greater the leader's use of the transformational style of leadership, the more positive is the influence on the employees' Islamic work ethic. Therefore, it may be that the employees have developed a perception of the quality of transformational leadership in their supervisor-subordinate relationship while at the same time they also exhibit commendable Islamic work ethic behavior in the organization.

In support of the theory of postulating a relationship between transformational leadership and ethical behavior of followers (Bass and Steidlmeier 1999; Brown and Trevino 2006), the results of this study favorably compare with the existing literature. This is in regard to the fact that transformational leadership has a positive impact on the ethical behaviors in the organization (Marshal et al. 2002; Crocker 2004; Keller 2007; Aswegen and Engelbrecht 2009). For instance, Crocker (2004) found that work ethics would increase more for the individuals working with leaders who often used the transformational style of leadership. The current finding is also consistent with the study conducted by Aswegen and Engelbrecht (2009) which used 203 employees from medium to large companies in Africa. They supported that transformational leadership has a positive effect on the dimensions of ethics in organization.

Furthermore, since this study was conducted in an Islamic organizational context, the leaders as Moslems are expected to articulate the Islamic values in their leadership behaviors. This should have an influence on the subordinates. Therefore, the Moslem subordinates of the transformational leader behaved in support of the leader's vision and mission of the Islamic organization. In general, such behavior, when repeatedly demonstrated would be followed by a supportive attitude on the behavior that was suitable to the Islamic values. The combination of behavior and attitude shown by their leaders, as role model, would produce an improved employee's Islamic work ethic.

Burns (1978) and Bass (1985) theorized that a transformational leadership behavior, such as, mentoring and coaching were effective. It is because they went beyond an economic exchange-based relationship between the leader and the follower towards a more psychological approach to leadership. According to Bass (1985) transformational leaders are perceived by their subordinates as being charismatic, inspiring, intellectually challenging and sensitive to the individual employees' concern.

In addition, this quality of Islamic ethical behavior possessed by a leader is reinforced in the four key factors that drive success for a transformational leader: charisma (idealized influence), inspirational motivation, intellectual stimulation and individual consideration (Bass 1985; Aswegen and Engelbrecht 2009). Idealized influence or charisma is the component of transformational leadership that determines the values and ethics that promote the follower's desire to be identified with their leaders. That is, leaders who have high ethics levels will serve as strong role models, which, in turn will inculcate a high standard of moral conduct in their subordinates (Avolio and Bass 2002). The transformational leader promotes ethical and morally uplifting policies and procedure in the organization (Bass and Steidlmeir 1999).

Inspirational motivation stems from a leader's ability and willingness to communicate and inspire high expectations to the followers (Bass and Stedlmier 1999). The inspi- 
ration may cause followers to believe in and act upon the leader's articulated vision. Since subordinates of a transformational leader behave in support of the leader's vision, such behavior when exhibited repeatedly would be accompanied by an attitudinal change to support the behavior. The combined behavior and attitude will produce improved employees' work ethics.

The transformational leader intellectually stimulates the employees. $\mathrm{He} /$ she does this by maintaining an open environment where the questions about the organization, including ethical conduct are warmly welcome (Bass and Stedlmier 1999). Intellectual stimulation implies a cognitive relationship between the leader and the follower that attains a higher level of awareness and consciousness. Particularly, the leader is able to challenge the old beliefs and value systems to propel his followers towards the organization's vision. Finally, individual consideration by a leader reflects a caring attitude and a genuine interest in developing each follower uniquely. Achievement in any one of these factors is a tall order to ensure the foundation of successful transformational leaders. Leaders who possess within themselves principled judgment, exemplary character, and high moral values will eventually develop the same attributes among their followers (Northouse 2009), especially, in an Islamic organization as used in this study. Transformational leadership style might elevate subordinate self-esteem, which would subsequently elevate the level of work ethics (Yulk 2006). This elevated self-esteem could also explain the increased work ethics performance observed among the subjects under study.

In terms of effect of Islamic work ethic, the results indicate that the relationships between the Islamic work ethics on both job satisfaction and organizational commitment are positive and significant. Furthermore, Islamic work ethic was also found to have negative significant influence on turnover intention. These findings are in line with the prior research (Yousef 2001; Koh and Boo 2001; Viswesvaran and Deshpande 1996; Vitell and Davis 1990). The majority of their findings demonstrated the positive impact of work ethic on organizational commitment and job satisfaction and negatively related to turnover intention.

\section{Conclusion}

This study examines the mediating effect of Islamic work ethic in the relationship between transformational leadership and job satisfaction, organizational commitment and turnover intention.

The study found that transformational leadership is an important predictor the Islamic work ethic behavior among the staff members in Islamic microfinance institution. In addition, transformational leadership has indirect effect on job satisfaction, organizational commitment, and turnover intention through Islamic work ethic.

The findings of this study have some theoretical implications. They offer some interesting guidelines for managers in Islamic microfinance organizations in formulating their human resource policies and strategies, especially the importance of developing ethics in the organization. In addition, in order to enhance job satisfaction and organizational commitment managers need to support the Islamic work ethic in their organizations. Thus, manager can ensure that every employee join training and educational programs that place more emphasis on the application of Islamic morality and values in work. 
Finally, there are some limitations to this study which need to be considered. First, the number of sample and organization is small, further study should use larger sample size and involve various industries in order to get better result. Second, the generalizability of the findings of the present study might be ques- tionable due to the nature of the sample. Third, the study's limited discussion on transformational leadership as single predictor of Islamic work ethic is noted. Nevertheless, there are some other factors which might predict Islamic work ethic, therefore, offering better explanations.

\section{References:}

Ali, J. A. and A. Al-Kazemi. 2007. Managerial problems in Kuwait. The Journal of Management Development 21 (5): 366-375

Ali, J. A. 1988. Scaling an Islamic work ethic. Journal of Social Psychology 128 (5): 575-583.

Ali, J. A. 2005. Islamic Perspectives on Management and Organization. UK: Edward Elgar Publishing.

Allen, N. J., and J. P. Meyer. 1990. The measurement and the antecedents of affective, continuance and normative commitment to the organization. Journal of Occupational Psychology 63:1-18.

Asgari, A., A. D. Silong, A. Ahmad, and B. A. Samah. 2008. Relationship between leader-member exchange, organization inflexibility, perceived organizational support, interactional justice, and organizational behavior. Asian Journal of Management 2 (8): 138-145.

Aswegen, A. S., and A. Engelbreacht. 2009. The relationship between transformational leadership, integrity, and ethical climate in organizations. SA Journal of Human Resource Management 7 (1):175-184.

Barling, J., A. Christie, and N. Turner. 2008 Transformational leadership: Towards the development and test of a model. Journal of Business Ethics 81 (4): 851-861.

Bass, B. M. 1985. Leadership and performance beyond expectation. New York: Free Press

Bass, B. M. 1990. From transactional to transformational leadership: Learning to share the vision. Organizational Dynamics (Winter): 19-31.

Bass, B. M., and P. Steidlmeier. 1998. Ethics, Aharacter and Authentic Transformational Leadership. http:// cls.binghamton.edu/BassSteid.html.

Baron, R. M., and D. A. Kenny. 1986. Moderator-mediator variable distinction in social psychological research: Conceptual, strategic, and statistical consideration. Journal of Personality and Social Psychology 51 (6): 1173-1182

Bartram, T., and G. Casimir. 2007. The relationships between leadership and follower in-role performance and satisfaction with the leader: The mediating effect empowerment and trust in leader. Leadership and Organizational Development Journal 28 (1):4-20.

Bozeman, D. P., and P. L. Perrewe. 2001.The effects of item content overlap on organizational commitment questionnaire and turnover cognitions relationships. Journal of Applied Psychology 86 (1): 161-73.

Beekun, R. I., and J. A. Badawi. 1999. Leadership, an Islamic Perspective. Beltsville, MD: Amana Publication.

Beekun, R. I. 2006. Strategic Planning and Implementation for Islamic Organizations (1 ${ }^{\text {st }}$ ed.). Herdon, VA, USA: International Institute of Islamic Thought.

Bollen, K. A. 1989. Structural Equations with Latent Variables. Wiley Series in Probability and Mathematical Statistics, New York: Wiley 
Brown, M. E., and L. K. Treviño. 2009. Leader-follower values congruence: Are socialized charismatic leaders better able to achieve it? Journal of Applied Psychology 94:478-490

Burns, J. M. 1978. Leadership. NY: Harper \& Row Publishers.

Byrne, B. 2001. Structural Equation Modeling with AMOS: Basic Concept Applications and Programming. New Jersey: Lawrence Erlbaum Associates Publishers.

Cairnes, M. 2003. People Power (February). CA: Charter.

Ciulla, J. B. 2003. The Ethics of Leadership. Belmont, CA: Wadsworth Publishing,

Chen, G., B. L. Kirkman, R. Kanfer, D. Allen, and B. A. Rosen. 2007. Multilevel study of leadership, empowerment, and performance in teams. Journal of Applied Psychology 92 (2): 331-346.

Croker R. 2004. The effect of leadership style on employee work ethic. Master Thesis submitted to California State University. USA.

Dubinsky, A. J., and S. W. Harley. 1986. A path-analytic study of a model of salesperson performance. Journal of the Academy of Marketing Science 14: 36-46.

Elizur, D., and M. Koslowsky. 2001. Values and organizational Commitment. International Journal of Manpower 22 (7): 593-599.

Engelbrecht A. S., A. S. van Aswegen, and C. C. Theron. 2005. The effect of ethical values on transformational leadership and ethical climate in organizations. South African Journal of Business Management 36 (2): 19-26.

Frey, M., R. M. Kern, J. Snow, and W. L. Curlette. 2009. Lifestyle and transformational leadership style. The Journal of Individual Psychology 65 (3): 212-240.

Furnham, A. 1982. The Protestant work ethic and attitudes towards unemployment. Journal Occupational Psychology 55 (4): 277-285.

Furnham, A. 1990. The Protestant Work Ethic: The Psychology of Work-related Beliefs and Behaviours. London: Routledge.

Furham, A., and R. Rajamanickam. 1992. The Protestant work ethic and just world belief in Great Britain and India. International Journal of Psychology 27 (6): 401-416.

Greenberg, J. 1990. Organizational justice: yesterday, today, and tomorrow. Journal of Management 16 (2): $399-432$

Hair, J. F., C. W. Black, B. Babin, R. E. Anderson, R. L. Tatham. 2006. Multivariate Data Analysis (5 ${ }^{\text {th }}$ ed.). New Jersey: Pearson Prentice Hall

Hom, P. W., and R. W. Griffeth. 1991. Structural equations modeling test of a turnover theory: Crosssectional and longitudinal analyses. Journal of Applied Psychology 76 (3): 350-66

Kanungo, R. N. 2001. Ethical values transformational and transactional leaders. Canadian Journal of Administrative Science 18 (4): 257-265.

Khali and Abu-Saad 2009. Islamic work ethic among Arab college students in Israel: Cross cultural management. An International Journal 16 (4): 333-346.

Kidron, A. 1978. Work values and organizational commitment. Academy of Management Journal 21 (2): 239247. 
Kirkman, B. L., G. Cheng, J. L. Farh, Z. X. Chen, and K. B. Lowe. 2009. Power distance and reactions to transformational leaders: Cross cultural examination. In Morgeson, F. Chair., and Zaccaro, S. Leadership in Group and Team: How and Why It Matters. Annual Conference of the Society for Industrial and Organizational Psychology. San Fransisco, CA.

Kline, R. B. 2005. Principle and Practice of Structural Equation Modeling ( $2^{\text {nd }}$ ed.). New York: Gildford.

Koh, H. C., and E. H. Boo. 2001. The link between organizational ethics and job satisfaction: A study of managers in Singapore. Journal of Business Ethics 29: 309-324.

Koh, H. C. and E. H. Boo. 2004. Organizational ethics and employee satisfaction and commitment. Management Decision 42 (5): 677-693.

Krishnan, V. R. 2001. Value systems of transformational leaders. Leadership and Organizational Development Journal 22 (3): 126-131.

Lewis, B. 1991. Turnover and the quiet crisis in the federal civil services. Public Administratrion Review 51 (2):145-155

Lim, C., and C. S. Lay. 2003. Confusiasm and the protestant work ethic. Asia Europe Journal 1: 321-322.

Luna-Arocas, R. and J. Camps. 2008. A model of high performance work practices and turnover intentions. Personnel Review 37 (1): 26-46.

McDonald, R. P., and M. H. Ho. 2002. Principles and practice in reporting structural equation analyses. Psychological Methods 7:64-82

Mulki, J. P., J. F. Jaramillo, and W. B. Locander. 2008. Effect of ethical climate on turnover intention: linking attitudinal and stress theory. Journal of Business Ethics 78: 559-574.

Peterson, D. K. 2003. The relationship between ethical pressure, relativistic moral beliefs and organizational commitment. Journal of Managerial Psychology 16 (6): 557-572.

Piccolo, R. F, and J. A. Colquitt. 2006. Transformational leadership and job behaviors: The mediating role of core job characteristics. Academy of Management Journal 49 (2): 327-340.

Pillai, R., C. Schriesheim, and E. Williams. 1999. Fairness perceptions and trust as mediators for transformational and transactional leadership: A two-study sample. Journal of Management 25 (6): 897-933.

Podsakoff, P. M., S. B. MacKenzie, and W. H. Bommer. 1996. Transformational leader behaviors and substitutes for leadership as determinants of employee satisfaction, commitment, trust, and organizational citizenship behaviors. Journal of Management 22 (2): 259-298.

Putti, J. M., S. Aryee, and T. K. Ling. 1989. Work values and organizational commitment: A study in the Asian context. Human Relations 42: 275-288.

Rahman, N. M., N. Muhamad, and A. S. Othman. 2006. The relationship between Islamic work ethics and organizational commitment: A case analysis. Malaysian Management Review 41 (1).

Rizk, R. R. 2008. Back to basics: An Islamic perspective on business and work ethics. Social Responsibility Journal 1 (2): 246-254.

Robbins S. P. 2005. Organizational Behavior. Upper Saddle River, NJ: Prentice-Hall.

Sager, J. K., J. Yi, and C. M. Futrell. 1998. A model depicting salespeople's perceptions. Journal of Personal Selling and Sales Management 18: 1-18.

Schminke, M., M. Ambrose, and T. Noel. 1997. The effect of ethical frameworks on perceptions of organizational justice. Academy of Management Journal 40 (5): 1190-1207. 
Schminke, M., D. Wells, J. Peyrefitte, C. Terrence, and T. C. Sebora. 2002. Leadership and ethics in work groups: A longitudinal assessment. Group \& Organization Management 27 (2): 272-293.

Schindler, D. R., and P. S. Cooper. 2001. Business Research Methods. (7 ${ }^{\text {th }}$ ed.). New York, NY: McGraw-Hill. Spector, P. 1997. Job Satisfaction: Application, Assessment, Cause and Consequences. London: Sage Publications.

Schwepker, C. H. 2001. Ethical climate's relationship to job satisfaction, organizational commitment and turnover intention in the salesforce. Journal of Business Ethics 54: 39-52.

Schumacher, R. E., and R. G. Lomax. 1996. A Beginner Guide to Structural Equation Modeling. Hilsdale, NJ: Erlbaum

Weeks, A., L. Terry, C. Loe, and W. Kirk. 2004. The effect of the perceived ethical climate on the search for sales force excellence. Journal of personal selling and sales management 24 (3): 199-214.

Weber, M. 2002. The Protestant Ethic and the "Spirit" of Capitalism. New York, NY: Penguin Classics.

Yousef, D. A. 2000. Organisational commitment as a mediator of the relationship between Islamic work ethic and attitudes toward organizational change. Human Relations 53 (4): 513-537.

Yousef, D. A. 2001. Islamic work ethic - A moderator between organisational commitment and job satisfaction in a cross-cultural context. Personnel Review 30 (2): 152-165. 